\title{
Translation and the Indian Tradition: Some Illustrations, Some Insights
}

\section{Priyadarshi Patnaik}

\begin{abstract}
In the context of the spotlight on translation in the postcolonial context, it is interesting to note that in the Indian tradition there are many instances of what can be termed 'translations' since very early times, yet there is hardly any theorizing in our tradition about them. The paper focusses on one instance of such an activity. Around $16^{\text {th }}$ century AD poet Jagannatha Dasa of Orissa wrote an Oriya Bhagabat which has virtually the exact chapter and canto arrangement as that of the Sanskrit Bhagabat. Yet there are variations here and there which are insightful. Similar is the case with the verses and the narratives which follow the Sanskrit Bhagabat systematically at many places and deviate at others. A close look at and comparison of the two texts leads to interesting observations. The paper uses a short extract each from the two works (Sanskrit Bhagabat with English translation, Oriya Bhagabat with my translation into English) to draw comparisons and to analyse some finer points of Indian translation in the pre-colonial days.
\end{abstract}

\section{Introduction}

At first glance, Indian tradition has nothing to say about translation. For that matter, there is hardly any theorizing anywhere in the Sanskrit scholastic or literary tradition about the translation of texts. Was it because there was no translation of texts in this tradition?

Translation Today Vol. 3 Nos. 1 \& 2, 2006 C CIIL 2006 
Since very early times translation has been a very significant activity in India. The Chinese came to India, took Buddhist texts back and translated them. Many Pali and Prakrit texts of the Buddhists were translated into Sanskrit. In the medieval period a number of popular Sanskrit works, especially Rāmāyana, Mahābhārata and many Purānas were translated into regional languages.

I subscribe to the view that translation has been an almost unconscious activity in the Indian tradition, something which has happened in this context effortlessly without fuss and hassles and, hence, has not received much critical attention. There are certain important components like the 'original text', 'author', 'cultural transference', etc., which were perhaps not problematized in the ancient Indian context, and hence, have drawn little critical attention. In the Western context as well, theorizing about translation is fairly recent, although the act of translation itself is at least as old as the Bible.

Today, a very important question comes to one's mind, and that is: is there anything distinctive that we can say about translation in the Indian context? As I pointed out above, one has very little critical text to go by which directly deals with translation. However, one can learn from the examples, from oblique references to the problem and even the way that the different art forms in our culture have evolved. For instance, one can look at translations among the different Indian languages that had taken place prior to colonization. One can look at Mimàmsa or the interpretative tradition for rules to be followed for interpretation; assuming that interpretation and translation have certain things in common. One can seek inspiration in the Jaina concept of anekāntavāda where reality can never be grasped in its totality (as any translation is always one of many possible translations of an ungraspable original). One can look at the way different art forms explored the same myths and legends - to what extent "translations" into different forms were parallel or used 
common principles. However, such an exploration would be a fulllength study in itself. What can be and are attempted here are some illustrations and pointers, with the hope that somebody would find them worthwhile starting points for detailed exploration.

I shall take up for close analysis a passage from Srimad Bhāgavata Mahāpurāna and its translation into Oriya. I shall then attempt to show that Indian aesthetics does give certain insights into the process of translation.

\section{Section I}

Medieval India saw the "translation" of many popular Sanskrit works into the regional languages - especially religious and didactic works to which the masses, who did not know Sanskrit, sought access. In Orissa Bhāgavata Mahāpuran was translated into Oriya sometime around the $15^{\text {th }}-16^{\text {th }}$ century A.D. by the eminent Santha poet Jagannātha Dāsa. The translation is remarkably popular even today and in Orissa hardly anyone reads the Sanskrit text. Almost all public readings in villages are from the Oriya Bhāgavata.

What I have attempted here is a comparison of a short passage from the $11^{\text {th }}$ canto of both the texts. However, before that, I would like to point out that in terms of metre, the two texts are very different. The Oriya text used a metre with nine syllables known as nabākshyari chhanda which is very popular in the Orissan tradition and is eminently readable over long stretches. This is also a metre which is easy to remember. The poet, thus, has chosen a metre which is not necessarily close to the original metre (the Sanskrit text was written mostly in anustuv metre), but one which, in its own cultural context, is the most appropriate. Since the Bhägavata is a long work and yet is supposed to be read in a matter of a few days, in Oriya, there is no other metre which is as lucid and easy to recite as the nabākshyari. 
Culture provides certain insights into how a work is looked at. In the Oriya tradition, it is never felt that Jagannātha's Bhāgavata is a translation of Sanskrit Bhäghavata. I believe this is common to the Indian context. We talk of Valmiki's Rāmāyana and we also talk of Tulsi's Rāmāyana or Kamban's Rāmāyana. It is never felt that one is the original and the other is a copy. It is as if the story of Rama exists somewhere in the Indian tradition and each poet has made it his own. Within the tradition, it is cultural property. Anybody can pick it and use it. Ownership of the story belongs to no individual but to a collective tradition. Often scholars use the expression "transcreation" to look at such works.

While Jagannātha's Bhāgavata fits this category, it is also remarkably close to the structure of the original. The numbers of cantos in both the texts are identical. The chapters are usually of the same number and each chapter deals with identical subject matter. Seen in this light, the Oriya text comes very close to what we call 'translation' today. This is one reason why it is a good example to take up here.

What I shall attempt now is a comparison of the two texts. For those who know both Sanskrit and Oriya, the original passages are available in the notes. However, for those who must read in English, given below are the translations. The translation from the Sanskrit is by C. L. Goswami (Goswami: 1995). The translation from Oriya is mine. In spite of the translations of translations, I hope that I will be able to make a few pertinent observations about the practice of translation in the Indian context.

The passage that I take up here is from the section that deals with the lessons that the Abadhuta learns from his twenty-four gurus. Among his gurus are the sky, the earth, the sea, animals and insects. The Abadhuta also learns from the experiences of the fallen woman - here the prostitute Pingalā who lived once in the town of Videha. 
Srimad Bhāgavata Mahāpurāna (Sanskrit) ${ }^{1}$

Canto 11. Chapter 8. Verses 30-34

Alas! How senseless and of uncontrolled mind am I! Behold the extent of my foolishness; ignorant as I am I have expected the fulfillment of my desire from a trifling mean paramour! (30)

Forsaking the eternal and real lord who resides in my heart and gives joy and wealth forever,

Fondly have I sought a poor man who cannot satisfy my desires and who only gives grief, fear, worry, sorrow and infatuation. (31)

Lo! How uselessly have I afflicted my soul by leading the life of a courtesan and living by such a highly reproachable profession;

I expected wealth and satisfaction from a lustful, greedy and lamentable person through the body sold to him. (32) What female other than myself would have enjoyed a body, which is like a house of which the framework is bones,

Covered with skin, hair and nails, which is full of urine and excreta and has nine doors through which constantly flows foul matter? (33)

Among the citizens of Mithila (Videha) I am the only foolish and wicked person...

\section{Bhāgavata Mahāpurāna (Oriya)}

Canto 11. Chapter 8. Verses 30-34

Look at the net of my desire!

I lived my time in ignorance,

Ruined everything in my lust for wealth,

In my woman's ways, in my carnal drive

Among unholy men

I indulged my desire intoxicated.

Curse this life of mine!

Close to me is my Deliverer, 
The giver of all wealth and happiness,

The Father of all orphans

The Lord of the path to liberation.

Distancing that pearl, that eternal Lord

From my cursed mind

I took to the company of wicked men.

Ignorant were my colourful ways.

They were very wicked and

Misfortune was the reason for my downfall.

For I lived among the debauch

As a result of the sins of my past life;

Was tormented in vein

With the ways of wicked womanhood.

Thirsting for money

I misused this body -

A cage made of bones

Covered with nail, skin and hair.

With chains and knots of veins

Smearing the skin with flesh.

In this house of body I stay.

Endlessly flow the nine openings.

Within which move urine and stool

Complete with phlegm, bile and...

Malodorous worms, saliva and veins;

Diseases grow here endlessly.

Such is the house where I reside.

This is what my Guru taught me.

Not paying heed to his words

In this house I am the -

In the whole city of Videha

There is no fool like me.

(Verses 30 -34)

While Jagannātha remains close to the spirit of the original, discusses the same themes, takes up the same issues, he also introduces variations of his own, extends certain metaphors, sometimes intensifies certain images and often elaborates and 
elucidates. In other words, there are places where the translation also extends into commentary.

To begin with, the content of the four verses of the Sanskrit text are covered in around 20 short verses in the Oriya Bhägavata. As indicated earlier, the metre is different, the approach elucidatory, giving rise to certain repetitions that one doesn't find in the Sanskrit text. This is an interesting point since by very nature, Oriya didactic poetry is repetitive. It is a part of this tradition. On the other hand Sanskrit verses are aphoristic more often and pithy, given as they are to condensation by the very compounding of words. Such attempt at pithiness hardly exists anywhere in the Oriya literary tradition and is in fact alien to it. While the Sanskrit Bhägavata is elucidatory in nature in the context of Sanskrit verse, compared to the Oriya text, it is very compressed.

The Oriya text, here, begins with a metaphor - one which is cultural and very powerful. He uses the metaphor of the net or the web for the world. Entrapment in the world of desires is the theme of both the texts, but in the Oriya text, the metaphor of the net is new. Māya Jāla or the "illusory web" of the world is a very common metaphor in Oriya religious poetry. The poet uses it here in the Oriya text to intensify the state of affairs with the fallen woman who feels entrapped.

Another interesting case is the use of extended metaphor and its elaboration. Both in the Sanskrit and the Oriya tradition, the body being seen as a 'cage' is a very powerful cultural metaphor. In the Bhakti poetry of the $16^{\text {th }}-17^{\text {th }}$ century Orissa, it is very frequently used. In this context, the Oriya text extends this metaphor, elaborates 
on it and highlights the disgusting elements that constitute this body. The reference to "diseases" is also new, not directly referred to in the Sanskrit text.

Is it not possible to go through a text, internalize it, and then express it in your own cultural context as cogently as possible? Is it not possible to take a metaphor and then extend it in order to intensify it? Is it not possible to elaborate, give flesh to stories or outlines that stand bare in the "original?" Is it not possible to get out of the mindset that makes one the "original" and the other the "copy?" I believe all these things happen when we look at "translation" in the Indian context.

Both the Sanskrit and the Oriya works seek inspiration prior to the beginning the work. If we had a translation in the literal sense, as we understand it today, the Oriya text would have sought the blessings for the poet of the Sanskrit text. But that does not happen. The Oriya text seeks inspiration and blessings for itself - its travails and smooth journey.

In this tradition, not only does the author internalize the text, but the text also internalizes the author. For instance, at the end of almost each chapter, Jagannātha says something like this:

The tale of these twenty-four gurus

Uddhaba tells, O Chakrapāni.

That tale is one of great delight.

And this is the summary of the eleventh canto...

Jagannātha Dāsa tells this

Setting his mind at the feet of Lord Krishna. ( $11^{\text {th }}$ Canto, chapter 10) 
The author of the Oriya Bhägavata has made the text his own and is himself embedded within the text. This is another common feature of much medieval poetry of India.

The notion of translation, as we understand it today, involves an 'original author' and an 'original text'. Faithfulness, devotion, textual integrity are highlighted; or else one rebels against them; they are never transcended. In the Indian tradition, internalization and transformation appropriate to the cultural context are indicated. Even as the author absorbs, the author is absorbed too.

However, a word of caution! Not all texts are or can be treated in this way, even in the Indian tradition. For instance, there was hardly any attempt to translate the Vedas into any other language prior to colonization. Vedas are apaurusheya (= not manmade), and are transmitted by sruti (= listening). They cannot be made one's own the way the Purānas can be. From the point of view of content, the meaning of the Vedas is embedded in the sound. Meaning proliferates at various levels - only one of them is literal. At another level meaning and sound are so closely linked that separating them divests them of all meaning. Mantras thus become untranslatable (Roy: 2004).

But the same is not the case with Bhagvad Gitā, which is considered anonymous in origin. In the Oriya language itself, there must be at least five Gitās between the $15^{\text {th }}$ and $17^{\text {th }}$ century A.D. The framework became so popular that almost any treatise on any religious subject started making use of it. In such a context, Gitā referred to the format (Krishna and Arjuna) and not to the content. What was translated, if at all it can be called that, was the form (even proforma) and not the content.

In the context of philosophical works, there were not many translations, at least from Sanskrit to the regional languages. For 
instance, I know of no translations of Sanskrit philosophical works into Oriya in the pre-colonial context. This could possibly be because those who indulged in philosophy were expected to know Sanskrit. It was the language of philosophy and there was no popular demand for philosophy as there was for Purānas or the epics.

An exploration of the translation of Pali canonical texts into Sanskrit would give us a lot of insight into the strategies followed in translating philosophical texts. However such an exploration would be outside the tether of this paper.

Let us now at Indian aesthetics and Indian poetics seeking some light on the act(ivity) we call 'translation'.

\section{Section II}

The various art forms, in the Indian context, are closely interrelated. This is indicated in many ancient treatises on art as I have pointed out elsewhere (Patnaik: 2004). For instance, the Visnudharmottara (Part 3, cpt 2, Verse 1-9), in a passage emphasizing the knowledge required to understand image-making, says:

Lord of men, he who does not know properly the rules of chitra can, by no means, be able to discern the characteristics of image... Without any knowledge of the art of dancing, the rules of painting are very difficult to be understood... The practice of dancing is difficult to be understood by one who is not acquainted with music... without singing, music cannot be understood.

(Kramrisch: 1928, 31-32)

In the context of dance, vāchikābhinaya (expression through words) can be easily translated into angikäbhinaya (expression 
through gestures) since an elaborate and well developed language of gestures exists which is capable both of description and narration.

Concepts like alamkara (ornamentations), dosas (defects), gunas (qualities), bhāvas (emotions expressed successfully through art) and riti (style) are common to music, painting, dance as well as literature. It is perhaps because of this interrelation that around the $16^{\text {th }}$ century A.D., there evolved a form of painting known as Rāgmāla . This is the depiction of the rāgas (musical forms) through a series of paintings. Such a radical conceptualization - translating something that is temporal and transient into something spatial and static - would not have been possible without a set up in which the various art forms shared many values, strategies and ideals.

Hence, stories belonging to the corpus of our tradition could be enacted in plays, dance forms, indicated in murals or paintings or transmitted through songs. A great degree of translatability among modes existed in such a tradition. Notions of authorship did not interfere with such translations or, as I have tried to suggest, 'transmutations'.

In the background of such inter-modal exchanges that Indian aesthetics permitted, it is not difficult to point to possible ways of translating between different languages and even cultures.

I shall begin with the observations that T.R.S. Sharma makes about Indian poetics and translation and then build on those ideas. In the context of rasa, he considered it the shaping principle, the inner rhetoricity working through the text and shaping it (Sharma 2004: 148-49). Rasa can also be considered the aesthetic emotion that pervades the work that gives it its emotion-based orientation. Unless this is successfully transmitted to the audience, according to Indian poetics, the work fails. The same principle can apply to translation. Though it looks apparently innocent, this can be radical 
when applied to translation - the translation may, if necessary, have to use totally different words or figures or configurations in order to successfully evoke similar emotions (to the source text) in another language or another culture. Thus, rasa, as a guiding principle, allows for departure from textual, word-for-word translation. If we look at Jagannātha's Bhāgavata, the different verse form used can be justified in these terms - the cultural difference required a different verse form which was lucid and seemed effortless. But I do not of course wish to indicate that Jagannātha's choice was necessarily based on rasa theory.

Riti refers to stylistics. Sharma differentiates it from rhetorics which also includes tropes or figures of thought (Sharma 2004: 149). Riti indicates the choice of language, the tone, the swiftness or slowness of pace, the static or the dynamic aspect of the language, the choice of verse. If rasa is the spirit that runs through the work, riti is the body, its fluidity or rigidity, its movements, its rhythms.

How does one emulate riti in a translation? Sharma gives the example of Hemingway. Since Hemingway uses a predominantly Anglo-Saxon diction and simple sentences, in an Indian translation, the use of colloquial rather than Sanskritised expressions could be indicated. Riti requires an acute ear, and the ability to choose an apt cultural 'transference'.

An elaboration of this point may be in order here. Often cultures cannot be translated. A different ethos has a different demand. A tone, a style, a narrative strategy may not exist in the translated language. Here one cannot translate; one must look for a cultural parallel. And in doing so, one goes not so much by riti as by rasa.

Alamkāras constitute figures of sound and thought. Metaphors, tropes, different kinds of figures come under it. While 
being considered as the supreme attributes of literature till the $10^{\text {th }}$ century A.D., after Ânandavardhana and Abhinavagupta, these came, often, to be considered as mere embellishments. Alamkāra or jewelry is that which adorns the bare body and thus makes it beautiful.

In translation, one tries to translate figures of thought, but what about figures of sound? What about the vibrations. As with mantras which lose their meaning in translation (since the vibration of the original sounds are missing), with sabda (sound) alamkära, translation usually fails.

Sharma finally talks of dhvani, which is a force-field of meanings, often culture-specific (Sharma: 2004, 150). Dhvani was brought into the realm of poetics by Ânandavardhana and is generally translated as 'suggestion'. For instance, Ganga (which could be someone's name) brings in the association of the holy river, the myth of Ganga and Shiva, the image of sacrifices, the sacredness of the water. This may pose problems for translation. Dhvani is to a very great extent culture-specific and poses the most difficulty to a translator. However, many texts rely on evocation and suggestion. Hence, dhvani is an important issue that translators must keep in mind. A strategy that some translators use is implicit commentary within the text in order to explain possible evocations. Others use notes and leave the rest to the reader's imagination. But there is no easy way to tackle the problem.

One other set of elements of Indian poetics that Sharma does not mention or consider important for translation is dosas (defects) and gunas (positive qualities) that one identifies in a text. Indian poetics lays down a series of defects (usually ten in number by each ancient critic) and good qualities of literary writing. While in the contemporary context we may no longer use the same guidelines, they are significant indicators of writing strategies. 
For instance, here are a few dosas and gunas that Bharata lists. Among gunas he indicates slesa (apt use), prasada (clarity), samatā (evenness), mādhurya (sweetness) etc. Among dosas he lists qudarthā (circumlocution or difficult words), arthantara (digression into irrelevance), arthahina (incoherence, multiple meanings), ekārtha (tautology) etc.

Dosas and gunas, we must admit, are both context- and culture-dependent and hence relative. Say, 'sweetness' may not be apt in all writings. In some, it may even be considered a defect. Nor is it the translator's main job to identify 'defects' in the text and remedy them. But dosas and gunas are insightful indicators of the subtle nuances of the style of writing. They get linked to riti or stylistics. They can make the translator choose the right strategy for emulating the style (or collage of styles) to be found in the text to be translated, be they dosas or gunas.

Finally, it must be said that the five elements of Indian poetics indicated above do not necessarily work in unity when one comes to translation. There might be inherently contradictory demands that each makes on the translator. If one goes by later poeticians in the Indian tradition, one would resolve the issue by focusing on rasa, the emotional evocation of the translation and its approximation to the text that is translated. Other elements must work in accord, and where they do not, must be subordinated to or abandoned in favour of rasa.

I also subscribe to such a view. In spite of the various things that we have to say in literary theory about texts, a very significant component of any act of literature is the response of the reader/audience to it, and this can never be purely intellectual or cerebral. Aesthetic relish always brings in certain emotions or their evocations. All translations must finally be read/experienced, and they must evoke certain aesthetic emotions in the reader/audience. In 
that every literary work can be analyzed through rasa and it can be a guiding principle for any transaltion.

\section{NOTES}

1. Srimad Bhagavata Mahāpurāna, Gorakhpur Gita Press, Gorakhpur, (3 ${ }^{\text {rd }}$ Edition) 1995.

2. aho me mohobitatim pasyatābijitātmanaḥ| yā kantādastạ

kāmam kāmaye yena bālisāa (30)

santam samipe ramanamratipradam bittapradam nityamimam bihāya I

akāmadam dukhhabhayādișokamohapradam tuch amahambhagegnyā (31)

aho mayātmā paritāpito bruthā sānketyabrutyati bigaryabartayā । strairnānrād yārthatřśsonosocyāt kř̀itena bittam ratimātmanechtī I(32)

yadasthi vinirmita bamsbangsyasthuṇam tvacā romanakheha pinardum 1

khyaranna badvāra magārametad birnmutrapurnam madupetikānya I (33)

idehanām pure hyāsminhamekeba muḍadihi

3. dekha mohara mohazāla I agyāne bancili mu kāla sarba nāsili dhana lobhe I nārī svabhābe kāmabhābe asādhu purusanka mele I kāntara bhāve kāmabhole ramili dhane dei mana I dhika e moharajībana nikate achi mora bhartā I sarba sampada sukha-dātā anātha nātha janahitā I mukati gatira bidhātā ze nitya purusa ratana I tāhānka dure thoi mana ramili kupuru sa sange I dhane surati sukha range buddhi mohara dusta ati I bipāka phale hīnagati banchili tuchajana mele I purba pātaka karmaphala 
bruthā tāpita heli muhịn I stirī lampate bhava muhin artha truśnāre hoi marta I e deha kali mu biartha asthi panjarā cāripāśe I chāu ṇi nakha roma keśe śirā śikuli gan thi jokhe I carma rudhira màmsa lepe e kāya ghare bāsa moro I nirate bahe nabadvāra ehā madhyare malamutra I sampurna kapha bāta pitta durgandha křumi lāla nādi $\mid$ aśesa roga chanti baḍi emanta ghare mote thoi I je guru gale śikhyā dei se guru bākya na pramaṇi I a ghere muhi docāruṇ̄ bideha nagarare thāi I mo pari mu ̣̣ha kehi nāhi

\section{REFERENCES}

Patnaik, P. 2004 "Translation, Transmutation, Transformation: A Short Reflection on the Indian Kala Tradition." in Translation Today, Volume 2, No 2 Mysore: Central Institute of Indian Languages.

Roy, Anjali.2004 "Mantra" in Translation Today, Volume 1 No1 Mysore: Central Institute of Indian Languages.

Sharma, T. R. S.2004 "Translating Literary Texts through Indian Poetics: A Phenomenological Study," Translation Today, Volume 1 No 1 Mysore: Central Institute of Indian Languages.

C. L. Goswami (tr) 1995 Srimad Bhagavata Mahāpurāna Gorakhpur: Gorakhpur Gita Press.

Stella Kramrisch (tr) 1928 The Vishnudharmottara Calcutta: Calcutta University Press. 
